Article

\title{
Sustainable European Transport System in a $100 \%$ Renewable Economy
}

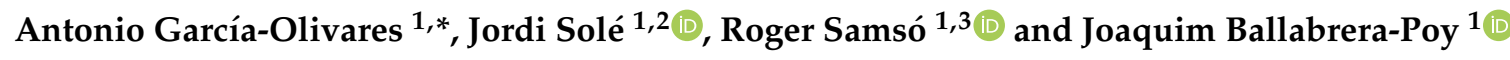 \\ 1 Institute of Marine Sciences, Spanish National Research Council (CSIC), Ps. Marítim de la Barceloneta 37-49, \\ 08003 Barcelona, Spain; jsole@icm.csic.es (J.S.); r.samso@creaf.uab.cat (R.S.); joaquim@icm.csic.es (J.B.-P.) \\ 2 Department of Mechanical Engineering, Universitat Rovira i Virgili, Campus Sescelades, \\ Av. Països Catalans 26, 43007 Tarragona, Spain \\ 3 Centre de Recerca Ecològica i Aplicacions Forestals (CREAF), Campus UAB, Edifici C, Bellaterra, \\ 08193 Barcelona, Spain \\ * Correspondence: agolivares@icm.csic.es
}

Received: 26 May 2020; Accepted: 17 June 2020; Published: 23 June 2020

check for updates

\begin{abstract}
Europe must move towards a 100\% renewable transportation system for climate, energy and sustainability reasons. We estimate the capital and energy required for building and operating a renewable transportation system providing similar services as the EU-28 transport system of 2016. It could be based on: biogas or fuel cell vessels; liquid biogas powered aircrafts; electric railways and fuel cell or electric vehicles between major cities; and car sharing, electric buses and electric two- and three-wheelers, for short journeys. A system of charging posts on the streets and roads for passenger and commercial e-vehicles is studied. Alternatively, a Tracked Electric Vehicle system of continuous power on European roads would improve energy efficiency and the saving of scarce metals ( $\mathrm{Ni}, \mathrm{Li}$ ), at a lower cost, if only national roads were electrified. The investment for the construction of the whole system would be $2.3-2.7 \%$ of the EU's GDP per year for 30 years. The new system operation would require $16 \%$ less energy than that of 2016 , with reduction of $70 \%$ in road transport. However, shipping and aviation would demand $162 \%$ and $149 \%$ more energy, respectively, if liquefied biogas were used as fuel. A type of land transport fully based on trains would provide a similar service to that of an electric vehicle fleet, with a $29 \%$ lower energy consumption.
\end{abstract}

Keywords: transport infrastructure; transition cost; electrification; embodied energy; decarbonisation; rail transport

\section{Introduction}

Transport is a fundamental instrument for the movement of goods and the free movement of persons in a globalized society. In 2016, the transportation sector represented 5\% (9\% including households cars fuels) of the total gross value added (GVA) of the European Union (EU) economy [1]. Logistics such as transport and storage account for $10-15 \%$ of the cost of a finished product for European companies [2]. Transport amounts to $17.2 \%$ (in 2016) of the EU's total exports of services. In 2017, the transport sector alone was responsible for greenhouse gas emissions of 946 million tonnes of $\mathrm{CO}_{2}$ equivalent, which corresponds to $27 \%$ of the total $\mathrm{EU}$ emissions [3]. In 2016, the transport sector consumed a third of the total final energy consumed in the EU (i.e., $353 \mathrm{Mtoe} ; 1$ toe $=4.1868 \times 10^{10} \mathrm{~J}$ ) [4]. Splitting up transportation into freight or passengers, inland freight transport in the EU-28 was estimated to be just over 2400 billion tonne-kilometres $(\mathrm{t} \mathrm{km})$ in 2016; around three quarters of this total was transported by road [5]. In passenger transport, cars accounted for $71 \%$ of the passenger-kilometres travelled in 2016, while air travel represented $10.5 \%$ of the distance travelled in the same year, followed by buses and coaches $(8.1 \%)$, railways $(6.6 \%)$, powered two-wheelers $(1.9 \%)$, tram and metro $(1.6 \%)$ 
and ship (0.4\%) [6]. In light of this, the EU is aiming to reduce its dependence on imported oil and, at the same time, cut transport carbon emissions by $60 \%$ by 2050 [7].

Numerous authors have pointed to the transition to a $100 \%$ renewable economy as a means to achieve the double objective of guaranteeing energy security and tackling climate change [8-10]. However, the economic overhaul required to make such a transformation raises legitimate doubts about whether it is possible while maintaining the services that the current system provides. García-Olivares [11] argued that its feasibility would greatly depend on our capacity to reach a stationary industrial economy. Accordingly, in this article we explore what a sustainable European transport sector would look like in the framework of a stationary economy.

Gilbert and Pearl [12] studied electric transportation systems for a post-carbon economy, but no cost estimation was provided. The Intergovernmental Panel on Climate Change [13] suggested some transport systems for a future post-carbon economy, while Teske et al. [14] showed that some transportation systems with low energy intensity are already available for a $100 \%$ renewable economy. King et al. [15] proposed a set of promising new technologies to electrify land transport. The International Renewable Energy Agency [16] studied different transition scenarios which suggest that a global sustainable transport is technologically feasible. Edelstein [17] analysed a catenary system for trucks that at that time was being trialled in Sweden with promising results. Swenson [18] proposed different new designs for a 100\% renewable economy, including the Solar Automated Nonstop Elevated (SANE) system for urban and metropolitan mobility. Thomas [19] reviewed the feasibility of different renewable powertrains for land transport, including fuel cell, battery and biogas vehicles. Arbib and Seba [20] proposed different ways to restructure the transport system, introducing the Transport as a Service concept, while Ram et al. [10] studied the energy and capital cost of a $100 \%$ renewable transition in Europe for all sectors but considered only one transition scenario for transportation. García-Olivares [11] and García-Olivares et al. [21] pointed to the need to rationalize the transportation structure when shifting to renewable electricity in a global decarbonized economy.

In this study, we estimate the capital and energy costs of reconverting the EU transportation system, using current or prototyped technologies, to one powered exclusively by renewable energy sources. Data used for this study correspond to the transport system of 2016, since more recent data were still unavailable or incomplete. Such calculations consider the capital cost of the vehicles, vessels, aircraft and trains, as well as the cost of the basic infrastructures needed to keep the system operative. One relevant contribution of the present work is the estimation of the cost of the complete substitution of the current EU land transport system with a railroad system. Indeed, we show that the already large electrification of the EU railways makes this scenario economically feasible. We use conservative hypotheses for the energy intensity (joules per USD) of manufacturing these infrastructures, which correspond to the upper range predictions of some life-cycle assessments (LCA) discussed in Section 2. Additionally, this work also refines the costs estimations of the world reconversion made by García-Olivares et al. [21].

\section{Materials and Methods}

In this section, we introduce the calculation methodology and the scenarios and sub-scenarios used in this work. The calculation methodology is applied across all scenarios and sub-scenarios. The flow chart in Figure 1 summarizes the calculations made in the two main scenarios studied. In Section 4, we also consider mixed scenarios that combine the best qualities of the scenarios analysed here. 


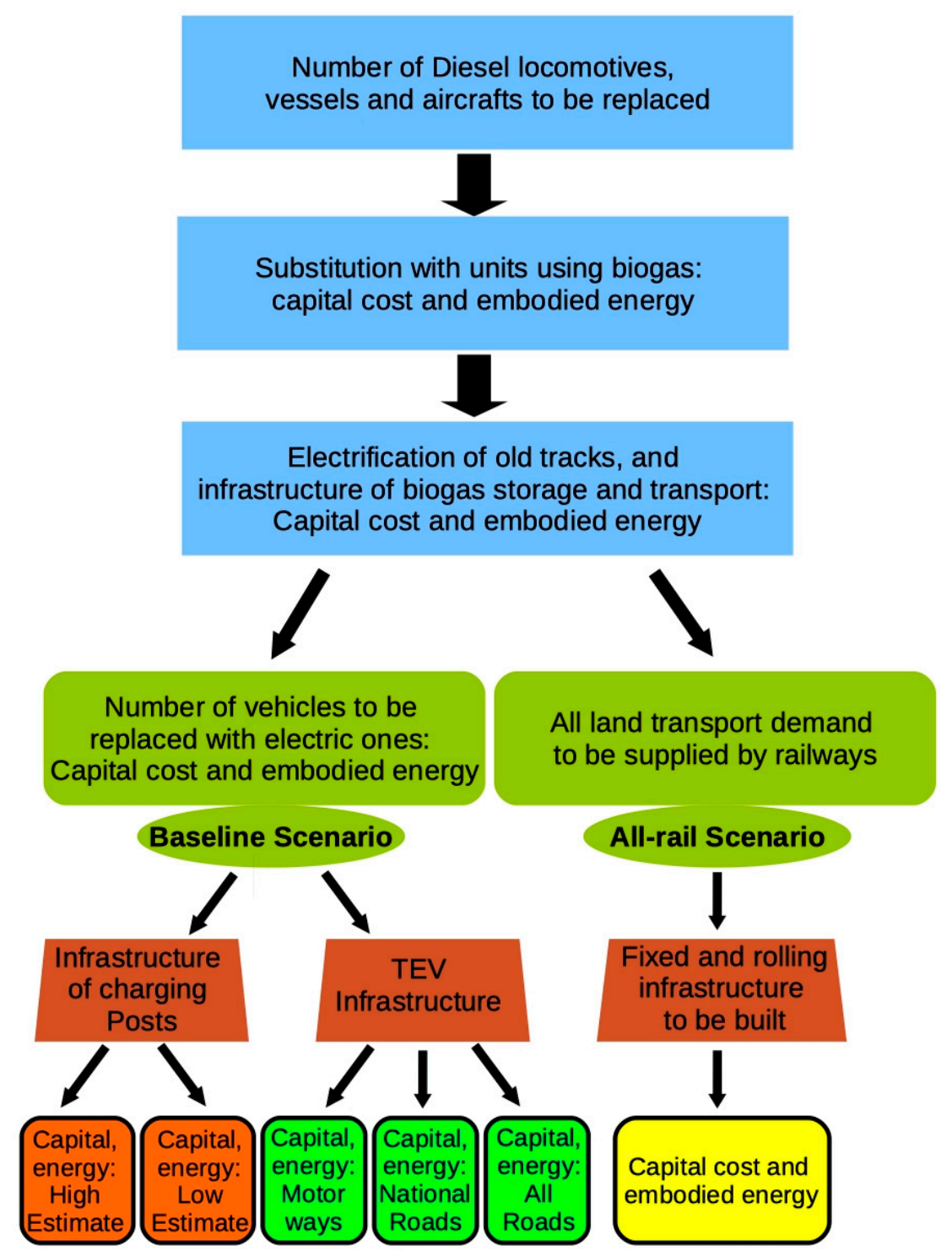

Figure 1. Flow chart of the calculation methodology followed in this study.

\subsection{Scenarios}

Baseline scenario. In this scenario the fleet of transport units (vehicles, trains, ships, and aircraft, respectively) of 2016 is assumed to be fully replaced with an equal number of transport units, powered by electricity or biomethane.

First, we estimate the gross investment in the manufacture of these fleets and their support infrastructures, and on that basis, the embodied energy in that capital.

This baseline scenario considers two sub-scenarios in which road transport is the differentiating factor. For the first sub-scenario charging posts are considered in the analysis while for the second sub-scenario Tracked Electric Vehicle (TEV) is studied as an alternative.

The analysis of this scenario leads to the proposal of some alternative decarbonized scenario.

The all-rail scenario considers the building of new infrastructure of electric locomotives and railways able to supply the same service as that provided by the whole land transport of 2016; for this, the statistics of passenger-km and tonnes-km transported in 2016 in the EU are used. This is an extreme scenario, but it will be a limit scenario of reference to discuss other intermediate possibilities (Section 4).

In the final discussion, we try to overcome some of the issues and bottlenecks of the two main scenarios. For instance, we consider the potential use of hydrogen and jet biofuels (instead of liquid 
bio-methane) in future aircrafts, and the reduction of the size of the future aircraft fleet. We also discuss the combination of the scenarios shown in Figure 1.

In the final discussion, we provide estimates for the transition expenditures and the fractions of GDP investment required to drive the transition towards the main scenarios considered.

\subsection{Calculation Methodology}

In each scenario, we estimate the cost in US dollars (USD) of the replacement of each transport sector by renewable alternatives, using the present market price of the main modes of transport. Then, we estimate the embodied energy associated to that capital, without considering the additional costs required for new electric vehicle maintenance, the expansion of the general electrical network, the renewable energy production infrastructure, or investments in associated research and development.

A precise calculation of the embodied energy in the new transport infrastructure would require a complete life-cycle assessment (LCA) of each class of transport unit using either a bottom-up or a top-down approach [22]. A bottom-up LCA maps every process associated with a transport unit and associates energy inputs with each process. The analysis is very detailed, but it is usually time- and effort-intensive due to heavy data requirements, especially when the first, second, third, etc., supplier levels are included. The exclusion of some of these suppliers may lead to an underestimation of the embodied energy. Top-down LCA associates economic output from a sector (given in producer prices of steel manufactured, assembled car, etc.) with the respective associated energy. This results in an industry-wide assessment, but with a larger uncertainty in the real energy cost of the specific transport units. Both approaches require analysing, one by one, all the transport units and infrastructures involved in European transport, which is beyond the scope of this study. Instead, we make an estimation of the embodied energy in each transport unit or infrastructure using a simplified top-down estimation, which we explain below. The results are compared in Section 3.7 with the annual energy consumed by the transport sectors in 2016 and in a future $100 \%$ renewable economy.

The production cost of a transport unit (e.g., a car) essentially includes the added value of the vehicle construction industry (with its characteristic energy intensity) plus the cost of direct energy and raw materials, which have different energy intensities because they have been produced by different economic sectors. García-Olivares et al. [21] assumed that the energy intensity of producing one transport unit corresponded to its final product in the transport equipment sector, because it is there where the main part of the added value is generated. However, this simplification may underestimate the embodied energy because transport equipment manufacturing accounts for only $12 \%$ of the average energy intensity of the industrial sector [23]. For instance, Volkswagen [24] made a detailed LCA analysis, which was in accordance with ISO 14040/44 standards, for the Golf 1.6 TDI BMT vehicle, and concluded that the vehicle's construction involved an embodied energy of 66 GJ. Given that its price was approximately $27,450 \mathrm{USD}$, its embodied energy is $2.4 \times 10^{6} \mathrm{~J} / \mathrm{USD}$. This figure matches the energy intensity of the German industry, which is the country where the vehicle and its components were produced.

Lewis [25] compared two different LCAs of the Airbus A-320, A-330 and A-380 aircraft and observed that the estimated $\mathrm{CO}_{2}$ impact and embodied energy of their construction vary by one order of magnitude depending on the chosen approach (process-based LCA or input-output LCA). His conclusion was that the upper bound estimation was more reasonable: $2.1 \times 10^{7} \mathrm{~kg} \mathrm{CO}_{2}$ eq (and $2.7 \times 10^{14} \mathrm{~J}$ ), $5.1 \times 10^{7} \mathrm{~kg}$ oil eq (and about $6.4 \times 10^{14} \mathrm{~J}$ ), $8.3 \times 10^{7} \mathrm{~kg}$ of $\mathrm{CO}_{2}$ eq (and $10.3 \times 10^{14} \mathrm{~J}$ ), respectively. Given that the prices of those three aircraft in 2017 were 99, 233.8 and 436.9 million USD, respectively [26], their embodied energy per USD is estimated at $2.7 \times 10^{6}, 2.8 \times 10^{6}$ and $2.4 \times 10^{6} \mathrm{~J} / \mathrm{USD}$. This corresponds, respectively, to $113 \%, 115 \%$ and $99 \%$ of the mean energy intensity of the industry of the countries where Airbus manufactures its aircraft.

Thus, to translate the production cost of new transport infrastructure into its embodied energy, we will be conservative and use the energy intensity of the industry of the country (or group of countries) where the infrastructure is built. One kilogram oil equivalent (koe) is equal to $41,868,000$ joules. If it is the 
EU as a whole, the figure will be: 0.08 koe $/ \$ U S D 2005=0.08 \mathrm{koe} /(1.247 \$$ USD2016 $)=0.064 \mathrm{koe} / \mathrm{USD}$ [27], where the dollar inflation rate between 2005 and 2016 (24.7\%) has been used. From here onwards, \$USD2016 and USD refers to dollars at constant exchange rate, price and purchasing power parities in 2016.

To be consistent, the energy intensities used are multiplied by a factor of 0.93 in this study, as it is discussed in García-Olivares et al. [21]. The reason is that a 100\% electrified machinery industry will demand $87 \%$ of the energy required by a fossil-fuel-based machinery industry to provide the same service. This would decrease the energy intensity of the sector during the entire transition, which would have a mean value $93 \%$ of the initial value during the period. The industry energy intensity of different countries in 2016 is taken from Table B3 of Appendix B of García-Olivares et al. [21].

Finally, we give estimates of the energy required for a fully renewable transport sector. These include the shifting from fuel oil and kerosene to liquid biogas in the shipping and air sectors, or to other biofuels in aircrafts, and the amount of electricity required for running the whole sector.

\subsection{Evaluation of the Different Modes of Transport}

\subsubsection{Light-Duty Vehicles, Medium-Freight Trucks and Heavy-Freight Trucks}

The number of passenger cars, motorcycles, and buses (and coaches) on EU-28 roads was 259.5 million, 33.8 million and 849,600, respectively in 2016 ([1], p.88-91). The European Automobile Manufacturers Association [28] reports 31.6 million light commercial vehicles, and 6.3 million medium and heavy commercial vehicles (over 3.5 tonnes), for 2016. According to the accumulated registrations from 2003 to 2017 in the EU ([29], Figures 2-13, p. 22), trucks under 16 tonnes are approximately a third of the total, and trucks over 16 tonnes are approximately two-thirds of the total; for buses these percentages are approximately $50 \%$ each. In this work, we take these fractions as representative of the fraction of the corresponding vehicle class in relation to the total number of vehicles in use. Thus, the number of light $\left(n_{l}\right)$, medium $\left(n_{m}\right)$ and heavy $\left(n_{h}\right)$ commercial vehicles are estimated in the following way:

$$
\begin{aligned}
& n_{l}=31.6 \times 10^{6} \\
& n_{m}=(6.3 \times 0.33+0.8496 \times 0.5) \times 10^{6}=2.5 \times 10^{6} \\
& n_{h}=(6.3 \times 0.67+0.8496 \times 0.5) \times 10^{6}=4.6 \times 10^{6}
\end{aligned}
$$

The number of commercial vehicles that will use fuel cells will depend on the fraction of long-distance freight that is transported by road (and not by train) [21]. We assume that its number will only be $10 \%$ of the number of commercial vehicles. The rationale behind this assumption is the following: if that (or a larger) percentage were built on a global scale, then $59 \%$ (or more) of the platinum reserves would be required for manufacturing fuel cell anodes, thus jeopardising its use in other industry sectors [21]. The substitution of the road fleet requires the manufacturing of 289 million light-duty vehicles powered by battery motors (or fuel cells), 33 million electric motorcycles, 2.45 million medium-freight trucks and 4.6 million high freight trucks with fuel cell or battery.

The expression used to estimate the total cost in USD for the new fleet $\left(c_{v}\right)$ is the following:

$$
c_{v}=n_{1} \times p_{l}+n_{2} \times p_{2}+n_{m d} \times p_{m d}+n_{h d} \times p_{h d}
$$

where $n_{l}, n_{2}, n_{m d}$ and $n_{h d}$ are the number of light vehicles, two- and three- wheelers, medium-duty trucks and heavy-duty trucks; and $p_{l}, p_{2}, p_{m d}, p_{h d}$ are some typical market prices of these kinds of electric vehicles in 2017.

The 25 best-selling light vehicles in the EU [30] have their factories in the EU, except the Ford Focus, which is produced in China, and a small proportion of the Dacia Sandero, which comes from outside the EU. On the other hand, the heavy trucks market is dominated by European brands such as Scania, Volvo and Renault [31]. Thus, we calculate the embodied energy using the energy intensity of the EU industry as a whole. 


\subsubsection{Water Transportation}

As discussed in García-Olivares et al. [21], a biogas economy would require fewer changes than a hydrogen economy in the shipping and aviation sectors and would have lower security concerns. In the shipping sector, biogas could be used in combustion engines or as a source of hydrogen for a fuel cell. Thus, it will be our fuel of reference for these two sectors in all the scenarios.

The fraction of global shipping that corresponds to the EU-28 can be defined in different ways (looking at the owners of the ships, the ships that exchange goods in European ports, etc.) We have chosen to assign to EU-28 the same distribution of ship types that sail the world, but in a fraction equal to that existing among shipping bunkers in EU ports with respect to world shipping bunkers. This fraction is 0.22 according to IEA Sankey diagram [32] and Eurostat [33]. The cost of the whole vessel fleet $\left(c_{c b}\right)$ for the EU is estimated as follows:

$$
c_{c b}=\left(p_{p a}+p_{c h}+p_{c o}+p_{c a}+p_{b u}\right) \times b_{f}
$$

where $p_{p a}, p_{c h}, p_{c o}, p_{c a}$ and $p_{b u}$ is the aggregated price of the world fleet of passenger, chemical, container, cargo and bulk carrier, respectively; and $b_{f}$ is the fraction of shipping bunkers in the EU-28 in relation to the world shipping bunkers (0.22). The cost of fishing vessels is calculated separately in a similar form. The number of ships for the main sub-categories of each of the aforementioned classes, and their prices, are discussed in García-Olivares et al. [21].

We assume that oil tankers will no longer be necessary in a $100 \%$ renewable economy, and that they will progressively be decommissioned as a global decarbonized system takes over. For this reason, they have not been considered in these calculations. Biogas production is assumed to be essentially regional (from fermentation and electricity), and it is assumed to be transported by road or pipes [21]. Olefins, which are the essential components of the petrochemical industry, will probably continue to be produced from petroleum during the transition, but in the long term they will have to be produced from biogas and charcoal in a fully sustainable economy [11]. Both materials are supposed to be produced in nearby locations and transported by land. The maritime coal trade was $26 \%$ of the dry bulk trade in 2004, according to Thien [34]. Assuming that this share was approximately the same in $2016,26 \%$ of present bulk carriers would no longer be necessary in a future $100 \%$ renewable economy, since we assume that charcoal for mineral reduction will be transported from nearby locations [11].

We use the energy intensities of the industry of the 14 main vessel-producing countries (see [21]) to estimate the embodied energy associated with this cost.

\subsubsection{Electrification of railways}

The length of EU-28 railway lines and tracks in 2016 was 227,383 and $349,276 \mathrm{~km}$, respectively ([35], Figure 63). Assuming that lines with more than two tracks are very infrequent in comparison with single and double-track lines, we obtain that $46.4 \%$ of the lines were single-track and $53.6 \%$ double-track. In 2016, 54\% of the total railway length was already electrified ([1], Section 2.5), thus we calculate the cost of electrifying the remaining 46\%. According to ECMT ([1], Section 2.5), the length of high-speed lines was $8,434 \mathrm{~km}, 7.2 \%$ of the length of the electrified lines in 2016 . We assume that this proportion of high-speed lines, as well as the present proportions of single- and double-track lines, will remain stable in the future. All lines other than high-speed ones are assumed to be medium-speed.

In Spain, the cost of the electrification of high-speed $(350 \mathrm{~km} / \mathrm{h})$ double-track railways was about one million EUR per km; with a speed of around $160 \mathrm{~km} / \mathrm{h}$ (medium-speed), the cost of double-track lines is about $0.40 \times 10^{6}$ EUR per km [36]. However, Gattuso and Restuccia [37] report 0.7-1.2 million EUR for double-track lines, and 0.5-0.9 million EUR for the single-track ones. We consider $0.5 \times 10^{6}$, $0.7 \times 10^{6}$ and $1.2 \times 10^{6}$ EUR as median values for medium-speed single- and double-track lines, and high-speed double-track lines electrification, respectively. 
The cost of the electrification of the EU railways $\left(c_{e r}\right)$ is estimated as:

$$
c_{e r}=0.46 l \times\left(c_{1} \times f_{1}+c_{2} \times\left(1-f_{1}-0.072\right)+c_{3} \times 0.072\right)
$$

where $l$ is the present length of lines in the EU; $f_{1}$ is the fraction of single-track lines; and $c_{1}, c_{2}$ and $c_{3}$ are the mean costs of single-track, double-track and high-speed double-track line electrification, respectively.

The number of tonnes-km and passenger-km "units" transported in the EU in 2016 was $450.1 \times 10^{9}$ and $403.6 \times 10^{9}$, respectively, resulting in a total of $853.7 \times 10^{9}$ units [6,38]. From [39] and Chapter 2.6 of [1] we estimate the number of diesel locomotives $\left(n_{d l}\right)$ and diesel railcars $\left(n_{d r}\right)$ in the EU-28 at approximately 16,629 and 13,478, respectively, and the total number of locomotives and railcars at 33,432 and 34,307, respectively. When the information was not available for 2016 for any country, we used the figure of the last year available; when no information was available, we assumed that the number of diesel locomotives (or railcars) was $46 \%$ of the total number. The number of passenger coaches and freight wagons in 2016 can also be estimated, from the same sources, at about 61,950 and 437,453 , respectively.

We assume that diesel locomotives and diesel railcars will be fully replaced by new electric locomotives or electric railcars. The price of one electric locomotive (in M€) is about $W / 3+1$ [40] where $W$ is the output power (MW). Taking $W$ as $5.5 \mathrm{MW}$ for an average locomotive, the result is $3.7 \times 10^{6}$ EUR (after inflation 2001-2016). For the cost of a typical electric railcar we take $2.7 \times 10^{6}$ EUR, the mean value between the price of a Stadler Regio-Shuttle RS1 (about 2.1 million EUR) and the price of an Alstom Minuetto (3.3 million EUR according to [37]).

The manufacturing cost of the new rolling infrastructure $\left(c_{r i}\right)$ is estimated according to:

$$
c_{r i}=\left(3.7 \times 10^{6} \times n_{d l}+2.7 \times 10^{6} \times n_{d r}\right) \times d
$$

where $d$ is the EUR to USD conversion factor in 2016.

\subsubsection{Air Transport}

García-Olivares et al. [21] estimated that the world aircraft fleet for 2033 would consist of 63,220 aircraft, divided into seven classes: 3,918 would be regional, with less than 100 seats; 45,055 "narrow-bodies" with 100-210 seats; 10,685 intermediate "wide-bodies"; 3,562 large wide-bodies; 600 small freighters; 1300 medium-freighters; and 1000 large freighters. We estimate the size of the EU-28 aircraft fleet assuming that the number of aircraft of a given class in the EU-28 is $26 \%$ of the number of the corresponding class in the world. This percentage corresponds to the size of the air bunkers of the EU-28 in comparison with the world air bunkers [32,33]. We estimate the cost of the EU-28 aircraft infrastructure assuming that $100 \%$ and $50 \%$ of all the projected demand for aircraft will be maintained in a future renewable transport system as in García-Olivares et al. [21].

The embodied energy in the new aircraft fleet $\left(e_{c a}\right)$ is estimated as:

$$
e_{c a}=\sum_{j=1}^{7} n_{j} p_{j} i_{j}
$$

where $j$ is an index (from 1 to 7 ) specifying the type of aircraft, $n_{j}$ is the number of aircrafts of class $j$, $p_{j}$ is the mean price of the aircraft of class $j$, and $i_{j}$ is the mean energy intensity of the industry in the countries where the class $j$ of aircraft is built.

\subsubsection{Infrastructure for Gas Storage and Transport}

We assume that the energy demand of the air and shipping sectors of the EU-28 in 2016 (see Table 1) will have to be supplied as biogas in the future economy. Then, we apply the methodology of García-Olivares et al. [21] to estimate the embodied energy in storage and gas infrastructure for a 
system of electric-trucks-based transportation at storage points with an average distance of $300 \mathrm{~km}$ and a storage time of seven days.

Table 1. Estimated energy that the present and future transport would use, by sector.

\begin{tabular}{ccc}
\hline Energy End Use & $\begin{array}{c}\text { Final Energy in 2016 } \\
(\mathbf{P J})^{*}\end{array}$ & Future Final Energy (PJ) \\
\hline Road & 12,567 & 3774 \\
Rail & 268.4 & $177.4^{\dagger}$ \\
Shipping & $1804^{* *}$ & 4735 \\
Air & 2233 & $4756 / 5560 / 9304^{* * *}$ \\
Pipelines/fuel transport & 69.6 & 17.9 \\
Total Transportation & 16,942 & $13,460 / 14,264 / 18,008^{* * *}$ \\
\hline
\end{tabular}

${ }^{*}$ From [33] ${ }^{* *}$ Obtained from the reported shipping bunkers for the EU-28 [33]. ${ }^{* * *}$ The three figures correspond to the use of hydrogen, methane and jet fuel, respectively, as aircraft fuel. ${ }^{+}$If an electric rail sector had to supply the whole demand of the land transport of 2016, except for motorbikes, the energy consumed by the sector would be 2796 PJ per year, and the road system would reduce its consumption from 3774 to 12.6 PJ per year.

\subsubsection{Electrical Charging System (Baseline Scenario)}

To estimate the cost of the charging system for the vehicle fleet batteries, we consider two sub-scenarios: (i) a system of electric charging posts located on the town streets and main roads, and (ii) the deployment of a Tracked Electrical Vehicles (TEV) system [41] of continuous power and charging on European roads.

(i) System of charging posts on streets and roads

In this sub-section, we introduce the methodology to calculate the costs of the posts required by (a) passenger vehicles, and (b) commercial vehicles.

(a) Posts for passenger vehicles

The mean distance travelled by car in towns and metropolitan regions in the EU $\left(c_{m}\right)$ was about $12,000 \mathrm{~km}$ per person [42], compared with $16,700 \mathrm{~km}$ in the USA [43] and $3800 \mathrm{~km}$ per person as a world average in 2012 [44]. A mid-range electric vehicle may have an autonomy of $125 \mathrm{~km}$, consume about $15 \mathrm{kWh}$ per $100 \mathrm{~km}$ [45] and have a battery charging time of 1 hour with a medium power $(22 \mathrm{~kW})$ charger. However, making a conservative estimation, we take $a=80 \mathrm{~km}$ per hour of charging, given that lower power chargers are also frequent for other kind of vehicles. Taking $o_{f}=1.5$ passengers per car as a typical "low occupation" figure [46], we find that in the EU, the service demanded by one person would require a mean of 100 hours of charge per year.

A functional (efficient/practical) system with a small fraction $f$ of unoccupied posts would have to be accompanied by a mobile application that would indicate to the user the nearest empty recharging posts. The number of posts $\left(N_{p}\right)$ needed for a municipality of $N$ people may be estimated as:

$$
N_{p}=N \times c_{m} /\left[8760 \times(1-f) \times a_{h} \times o_{f}\right]
$$

where 8760 is the number of hours per year. As an example, taking $f=0.33$ and with the EU average car mobility, the city of Barcelona ( $N=1.6 \times 10^{6}$ people; $102 \mathrm{~km}^{2}$ of surface) would need 268 recharging posts per $\mathrm{km}^{2}$. The average building block in the Eixample district of Barcelona, with the associated road lanes included, is $133.3 \times 133.3 \mathrm{~m}$. Thus, five posts per block would be required.

This is a conservative estimation that assumes that all the charge would be supplied by posts on the streets. In fact, Engel et al. [47] report that currently in the EU-28, 75\% of the charge of electric vehicles is made at home, and they project that home charging will be about $28-40 \%$ of the total after 2030 , with $47-59 \%$ of the charge being made in public stations on the street, $9 \%$ at work places, and $4 \%$ at highway facilities during long-distance travels. Thus, the number of charging posts calculated by 
Equation (6) would probably be spatially distributed in a similar way, thus alleviating the occupation of the streets.

The price of a Wallbox [48] recharging post of $22 \mathrm{~kW}$ is 1207 EUR per connection. Thus, the total cost of installing posts to satisfy the entire mobility demand $\left(c_{p 1}\right)$ is:

$$
c_{p 1}=1207 d \times p \times h_{c} /[8760 \times(1-f)]
$$

where $p$ is the EU's population in 2016, $d$ is the conversion factor from EUR to USD, $h_{c}$ is the number of hours of charging required by a typical driver of a car with low occupancy ( 1.5 persons per car), which is calculated as $h_{c}=12,000 /(a \times 1.5)$, where $a$ is the autonomy per hour of charging and 12,000 corresponds to the number of kilometres travelled by car per capita in the EU.

(b) Posts for commercial vehicles

The number and energy consumption of commercial vehicles in the world is obtained from IEA $[49,50]$ and Table 1 of García-Olivares et al. [21]. The energy consumed per year for one vehicle of a given class $\left(e_{a 1}\right.$ to $\left.e_{a 4}\right)$ can be obtained by dividing the corresponding values in column 2 and 3 of that table, and the results are 6.4 GJ (three-wheeler), 62.4 GJ (light vehicle), 231.5 GJ (medium-freight truck) and $619.2 \mathrm{GJ}$ (high-freight truck). The power ( $p_{p 1}$ to $p_{p 4}$ ) of the charging stations used by the four vehicle types is assumed to be $22 \mathrm{~kW}, 55 \mathrm{~kW}$ and $100 \mathrm{~kW}$ for three-wheelers and light vehicles, medium trucks and heavy trucks, respectively. The yearly accumulated charging time of each kind of vehicle $\left(t_{a i}\right)$ is calculated as:

$$
t_{a i}=e_{a i} \times c_{f} / p_{p i}
$$

where $i$ ( 1 to 4 ) represents the four types of vehicle, $c_{f}$ is a factor to convert joules to $\mathrm{kWh}$, and the other symbols are defined above.

Long charging times would probably affect the logistics of road transport, but it is difficult to predict if they would result in needing to add more vehicles to the fleet. In this study, we have assumed that transport logistics will be adapted so that commercial vehicles can be charged during the drivers' sleep, rest and mealtimes.

The $\operatorname{cost} c_{p 2}$ of the recharging posts for commercial vehicles is calculated as:

$$
c_{p 2}=p \frac{\sum_{i=1}^{4} n_{i} t_{a i}}{8760(1-f)}
$$

where $f$ is the fraction of unoccupied charging posts (assumed to be 0.33), 8760 is the number of hours per year, $p$ is the average price of a single post, $n_{i}$ is the number of vehicles of the kind $i$, and $t_{a i}$ is calculated by Equation (8). The price $p$ is assumed to be that of the Modo-4 Raption Trio model of Wallbox [48], 37,200 USD.

(ii) Cost of electrifying a road with the TEV system

Here we estimate the cost of electrifying a (dual carriageway) road with the TEV system on the EU roads. A system like this would have a set of advantages: (a) it would allow to reduce the number of long-range vehicles (probably powered by fuel cells); thus, fuel cells could be reserved for off-road vehicles; and (b) it would allow a decrease in vehicle battery size, saving on mineral utilization.

The length of motorways, national roads and total roads (including regional and secondary roads and highways and motorways) in the EU-28 is estimated at 74,341, 287,227 and 4,852,242 km, respectively [51]. To estimate the building cost of one kilometre of this system we assume that the work is done on already existing roads. Thus, the cost should be similar to that of the electrification of a double-track railway of $150 \mathrm{~km} / \mathrm{h}$, i.e., $0.38 \times 10^{6}$ EUR of $2011(459,000$ USD of 2016) per km (Section 3.4). Thus, the total cost of deploying the TEV system across the EU-28 $\left(c_{t e v}\right)$ can be estimated with the expression: $c_{t e v}=459,000 \cdot l_{r}$ where $l_{r}$ is the length of EU-28 roads. 


\subsubsection{Railways for the Entire Inland Transport System (All-Rail Scenario)}

The number of units (passenger-km) transported in the EU-28 in 2016 by buses and coaches and passenger cars is taken as 552 and 4829.3 billion $\left(10^{9}\right)$, respectively [6]. The number of units of freight (tonnes-km) transported in the EU-28 in 2016 by road was 1852.3 billion [38]. In total, $u_{2}=7234 \times 10^{9}$ units should be transported, in addition to the units that will be transported by the currently non-electrified lines.

The new railway line length $\left(l_{2}\right)$ required to supply such a service is estimated according to:

$$
l_{2}=0.5 l\left(u_{2}-u\right) / u-1
$$

where $l$ is the present-day length of EU-28 railroads; $u_{2}$ and $u$ are the number of units transported by road and train in 2016, respectively; and 0.5 is the mean used capacity in 2016 of the EU-28 network. Here we assume that: (i) the present and future railway network will be able to allocate twice the number of units it transported in 2016 in a future high demand scenario, thus, $u$ must be subtracted from the units to be transported by new lines; and (ii) the remaining demand will be allocated to new railway infrastructure, whose length will expand proportionally to that demand. The factor 0.5 is based on Rotoli et al. [52]. This reference shows that more than $90 \%$ of the EU network segments used less than $60 \%$ of their practical capacity, even with a conservative definition of practical capacity. In reality, most of the segments that seem to be saturated (mostly in Belgium) are not so when analysed on a small scale, or can reduce their used capacities to under $60 \%$ with minor investments. We consider a mean used capacity of $50 \%$ as a conservative estimation for the whole EU.

The cost of building new railway lines from scratch includes not only electrification (as considered

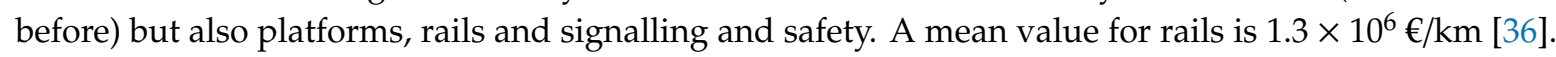
For signalling and safety, we take the upper range values reported by Gattuso and Restuccia [37]: $0.5 \times 10^{6}$ and $1.0 \times 10^{6} € / \mathrm{km}$ for single- and double-track, respectively. However, platform costs are very variable-from 4 to 20 million EUR depending on the terrain orography [36] — because they include ground levelling, tunnels and viaducts. Estimating the fraction of the length $l_{2}$ that would pass through flat, intermediate and rugged terrain would involve a country-by-country engineering analysis which is beyond the scope of this study. Here we make a rough estimate. The EU-28 countries have been classified as "flat", "intermediate" and "rugged" depending on their predominant orography. We consider as flat Sweden, Hungary, Poland, the Netherlands, Finland, Estonia, Latvia, Lithuania, Malta, Belgium, Luxembourg, Ireland, Denmark and the United Kingdom; we consider as intermediate France, Germany, Portugal, Cyprus, Romania, the Czech Republic and Slovakia; we consider as rugged Austria, Bulgaria, Slovenia, Spain, Croatia, Italy and Greece.

The rail track length in 2016 for flat, intermediate and rugged countries can be estimated from Figure 64 in [35] as $36.5 \%, 43.4 \%$ and $20 \%$ of the total, respectively. We assume that these figures will be the future proportions of rails passing through flat, intermediate and rugged terrain. We take the cost of building platforms for double-track lines in these three kinds of terrains as 4,10 and 20 million $€ / \mathrm{km}$ (EUR of 2011), respectively. These values correspond to the two extreme values of the range reported by Ferropedia [36] and to a median value of the range. For single-tracks, platforms are expected to cost $75 \%$ of the stated values [37].

Thus, adding to it the cost of electrification, rails and signalling and safety, the mean cost of single-track lines is estimated (for the three kinds of terrain) at 5.6, 11 and 20 million USD; double-track lines is estimated at 8.8,16.1 and 28.2 million USD, respectively. Ferropedia [36] suggests cost values for high-speed in the three kinds of terrain: $13.8 \mathrm{M€} / \mathrm{km}$ (EUR of 2007), $19 \mathrm{M€} / \mathrm{km}$ (EUR of 2010) and $33.3 \mathrm{M€} / \mathrm{km}$ (EUR of 2007), which is equivalent to 18.1, 23.4, and 43.7 million USD, respectively.

Assuming that the customary and largest stations are already built, we consider that one small stop (or repair facility) is built every $10 \mathrm{~km}$ throughout the length of new double-track lines. Single-track lines are assumed to be used mainly for freight (long-distance) transport, and high-speed lines are 
intended to connect only large stations, both of them with no small stops. A mean cost for a small stop is $4 \times 10^{6}$ EUR [37].

The total building cost $\left(c_{b r}\right)$ of the railway lines is then estimated as:

$$
\begin{gathered}
c_{b r}=c_{e r}+1_{2} \times\left[\left(c_{a 1} w_{a}+c_{b 1} w_{b}+c_{c 1} w_{c}\right) \times f_{1}+\left(c_{a 2} w_{a}+c_{b 2} w_{b}+c_{c 2} w_{c}\right) \times\left(1-f_{1}-0.072\right)+\right. \\
\left.\left(c_{a 3} w_{a}+c_{b 3} w_{b}+c_{c 3} w_{c}\right) \times 0.072\right]
\end{gathered}
$$

where $c_{e r}$ is the cost of the electrification of the EU's non-electrified railways, calculated by Equation (3); $l_{2}$ is the length of unbuilt lines; $w_{a}, w_{b}, w_{c}$ are the fractions of flat, intermediate and rugged terrain, respectively; $c_{a j}, c_{b j}, c_{c j}$ is the building cost (USD per $\mathrm{km}$ ) of lines of kind $j(j=1$ : single-track; $j=2$ : double-track and speed $120-150 \mathrm{~km} / \mathrm{h} ; j=3$ : double-track and high-speed) on terrain of kind $a$ (flat), $b$ (intermediate) and $c$ (rugged), respectively.

The cost of locomotives, railcars, passenger coaches and freight wagons necessary to supply such service is calculated with the following expression:

$$
c_{r 2}=c_{r i}+d \times 0.5 \times\left[\left(u_{2}-u\right) / u\right]\left[n_{1} c_{1}+n_{r c} c_{r c}+n_{p c} c_{p c}+n_{f w} c_{f w}\right]
$$

where $c_{r i}$ is the cost of the electrification of the present diesel locomotives and railcars (calculated by Equation (4); $d$ is a conversion factor from EUR to USD; $u, u_{2}$ refer to the number of units transported by train and road, respectively, in 2016; $n_{l}, n_{r c}, n_{p c}, n_{f w}$ are the numbers (in 2016) of locomotives, railcars, passenger coaches and freight wagons, respectively; $c_{l}, c_{r c}, c_{p c}, c_{f w}$ are the respective prices of these elements. Here we assume a doubling of the train utilization rate.

\subsection{Energy Required to Run a 100\% Renewable Transport System (Both Scenarios)}

Here we estimate the annual energy that a 100\% renewable transport system in the EU-28 would use and compare it with the energy used by the sector in 2016, using the same methodology as García-Olivares et al. [21]. We use Table 1 of the aforementioned reference for the efficiencies of different motors and the efficiency of the electricity-to-methane process that are considered in the calculations.

The expression used to estimate the energy demand of rail transport is:

$$
e_{t r}=\frac{e_{t}\left(0.54 \eta_{e l e}+0.46 \eta_{d}\right)}{\eta_{\text {ele }}}
$$

where $e_{t}$ is the energy required in 2016 by the railway transport sector of the EU-28; $\eta_{e l e}$ and $\eta_{d}$ are the efficiencies of electric (with overhead line) and diesel motors, respectively; and 0.54 and 0.46 are the fractions of electrified and non-electrified railways in the EU-28 (considered to be also the fractions of electric and non-electric locomotives).

An estimation was also made for the energy consumed by a rail transport system able to supply the whole land transport demand of the EU-28. The expression used is:

$$
e_{t r 2}=u_{p} \varepsilon_{p}+u_{w} \varepsilon_{w}
$$

where $e_{t r 2}$ is the energy $(\mathrm{J})$ consumed each year by the new renewable railway sector; $u_{p}, u_{w}$ are the number of units (passenger-km or tonnes- $\mathrm{km}$ ) of passengers or freight to be transported, respectively (estimated as $5.9 \times 10^{12}$ from [6] and $2.3 \times 10^{12}$ from [38]); and $\varepsilon_{p}, \varepsilon_{w}$ is the energy (J) consumed by an electric train per passenger or tonne transported, respectively (taken as $0.3 \mathrm{MJ} /$ passenger-km and $0.45 \mathrm{MJ} /$ tonnes-km, respectively, from [16]).

For air transport, the EU is taking a comprehensive approach to reduce GHG emissions, pollution and noise. It is taking action in three areas: (i) funding research and development for the "greening of air transport" with the aim of reducing $\mathrm{CO}_{2}$ emissions by $50 \%$ per passenger-km and $\mathrm{NO}_{\mathrm{x}}$ by $80 \%$ within the Horizon 2020 programme; (ii) deployment of a more efficient air traffic management system in Europe with one of the objectives being to reduce emissions by $10 \%$ per flight; (iii) measures to 
adopt sustainable alternative fuels, which are formulated in terms of the standardized process by an international fuel specification committee [53]. These alternative fuels follow along three general lines [54]: (1) fuels from vegetable oils and animal fats, (2) Fischer-Tropsch fuels (biomass-to-liquid, BTL), (3) synthetic Isoparaffin fuels from the conversion of sugars. However, the majority of these processes require quality crops, which account for GHG emissions themselves and might compete with food production. In addition, the production of jet biofuels consumes a large amount of electricity (Table 1). For these reasons, we consider the use of liquid biomethane the preferred option. We contemplate the production of jet fuels only as an auxiliary and temporary measure to alleviate the transition to a carbon-free economy.

\section{Results}

In this section, we estimate the costs of: full electrification of the different transport modes and the cost of infrastructure of liquid methane storage and transport (from renewable origin) required for shipping and air transport; the manufacture of charging stations to supply electricity to fleets of battery-powered vehicles; the building of a catenary-like system (TEV: Tracked Electric Vehicle) of continuous power and charging along all of the EU's roads. Finally, we estimate the annual energy consumed by the new renewable transport system and we compare it with the energy demand for transportation in 2016.

\subsection{Light-Duty Vehicles, Two- and Three-Wheelers, Medium-Freight Trucks and Heavy-Freight Trucks}

To obtain the cost of the new fleet of vehicles we use Equation (1), where the prices $p_{l}, p_{2}, p_{m d}, p_{h d}$ have been taken as: $22,800,5700,103,000$ and 284,000 USD, respectively. The resulting cost of the new fleet is $8.3 \times 10^{12}$ USD. The corresponding embodied energy is $21,512 \mathrm{PJ}$.

\subsection{Shipping and Air Transportation}

From Equation (2), the cost of the whole fleet of transport vessels would amount to $2.2 \times 10^{11}$ USD. The corresponding embodied energy is: 805 PJ for the EU-28.

For air transport, the estimated cost for aircraft demand is $9.7 \times 10^{11}$ USD. From Equation (5), the corresponding embodied energy is $1999 \mathrm{PJ}$.

\subsection{Railways}

Using Equations (3) and (4) (Section 2), the whole cost which correspond to railways and locomotives is $7.7 \times 10^{10}$ and $1.1 \times 10^{11} \mathrm{USD}$, respectively; $1.9 \times 10^{11} \mathrm{USD}$ in total. By multiplying this figure by the EU-28 energy intensity, the embodied energy in the new railway infrastructure is estimated to be 470 PJ.

\subsection{Infrastructure for Gas Storage and Transport}

The capital cost of infrastructure would be 20 billion USD, and the embodied energy of this capital is approximately $e_{g}=53 \mathrm{PJ}$. The annual energy required for this gas supply service is also estimated as $e_{m}=17.9$ PJ. This quantity is included in Table 1, under the entry "Fuel Transport".

\subsection{Electrical Charging System (Baseline Scenario)}

As detailed in Section 2, we estimate the cost of an electrical charging system in the two sub-scenarios.

\subsubsection{System of Charging Posts on the Streets}

(a) Posts for passenger vehicles

As of 2016, the EU-28 population was 510 million people. Using the conversion (for 2016) $1 €=1.13$ USD, we obtain from Equation (7): $c_{p 1}=1.2 \times 10^{10}$ USD. 
(b) Posts for commercial vehicles

To estimate this cost, we use Equation (9). The result is $c_{p 2}=2.1 \times 10^{11}$ USD. The total cost of posts for the EU-28 is $c_{p}=c_{p 1}+c_{p 2}=2.3 \times 10^{11} \mathrm{USD}$.

To obtain an upper range estimate of the cost, we assume that each of the EU vehicles (except for motorcycles) will have its own charging post. In this case, the cost obtained for $c_{p}$ is $6.5 \times 10^{11}$ USD.

Using the EU mean energy intensity of the industry, the embodied energy associated with that range for the EU-28 would be $e_{p}=567$ to $1632 \mathrm{PJ}$.

\subsubsection{Cost of Electrifying a Road with the TEV System}

The final costs for the electrification of the EU-28 roads are $3.4 \times 10^{10}, 1.3 \times 10^{11}$ and $2.2 \times 10^{12}$ USD for motorways, national roads and total roads, respectively. The associated embodied energy would be 76,294 and 4967 PJ if motorways, national roads, and all the roads were electrified, respectively.

\subsection{Railways for the Entire Inland Transport System (All-Rail Scenario)}

In this scenario, as explained in Section 2, the whole cost of infrastructure associated with the new railway lines, estimated by Equation (11), amounts to $1.2 \times 10^{13}$ USD. The cost of the rolling infrastructure associated with it is calculated with Equation (12) and amounts to $1.8 \times 10^{12}$ USD. The total cost of the new infrastructure would be $1.4 \times 10^{13}$ USD. The embodied energy of the new railway infrastructure is estimated at $34,744 \mathrm{PJ}$.

\subsection{Energy Required to Run a 100\% Renewable Transport System}

The energy that the different transportation sectors used in 2016 and the energy that the same sectors would require a 100\% renewable system is summarized in Table 1 . This is shown in graphical form in Figure 2 for five scenarios: transportation of 2016; baseline scenario with aircrafts using hydrogen, liquefied natural gas (LNG) and jet biofuel, respectively; and the all-rail scenario.

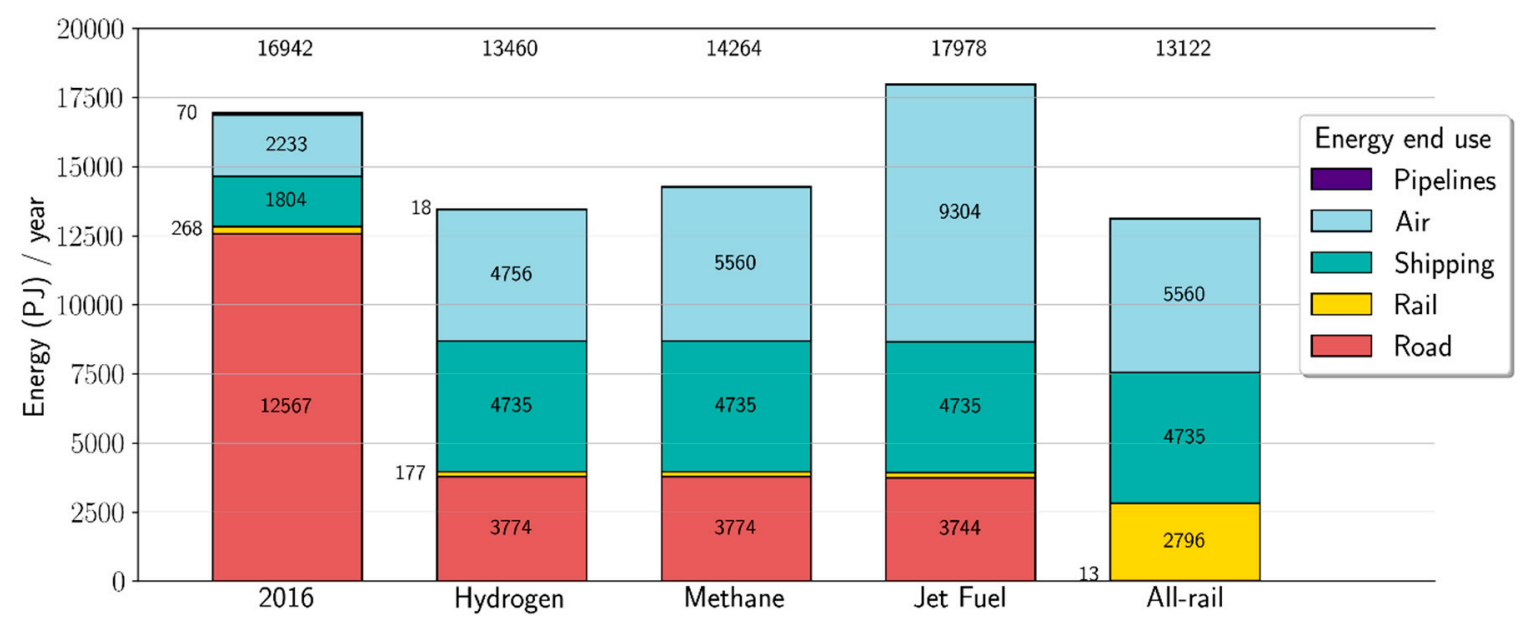

Figure 2. Total energy demand of the transport sector and its five sub-sectors, for five scenarios: transportation of 2016; baseline scenario with aircrafts using hydrogen, methane and jet biofuel, respectively; and all-rail scenario.

Table 2 summarizes our cost estimates for the new transport infrastructure. The direct cost of the new electric transport units would be almost 9800 billion USD; $85.8 \%$ for manufacturing the vehicle fleet, $10 \%$ for the fleet of aircraft with new engines, $2.3 \%$ for the ships with new (biomethane or fuel-cell) drive shafts, and $1.9 \%$ for the electrification of locomotives and catenaries. If the cost of recharging stations and gas transport system is added, the total rises to 10,041-10,467 billion USD. 
Table 2. Capital and energy costs for our transition scenarios.

\begin{tabular}{ccc}
\hline Sector & Capital Cost (Billion USD) & Embedded Energy (PJ) \\
\hline Light-duty vehicles & 6637 & 17,145 \\
Medium- and heavy-duty trucks & 1576 & 4072 \\
Two- and three-wheelers & 193 & 498 \\
TOTAL VEHICLES & 8400 & 21,714 \\
Railways & 77 & 192 \\
Locomotives & 111 & 278 \\
TOTAL RAILWAYS & 188 & $470^{\dagger}$ \\
Bulk carrier ships & 84 & 302 \\
General cargo ships & 24 & 85 \\
Container ships & 61 & 220 \\
Chemical tankers & 21 & 75 \\
Passenger ships & 34 & 123 \\
TOTAL SHIPPING & 224 & 805 \\
Aircraft & $975 *$ & $1999 *$ \\
Recharging stations/ & $228-653 /$ & $567-1632 /$ \\
TEV system & $34 ; 132 ; 2228 * *$ & $85 ; 329 ; 5566 * *$ \\
Biomethane infrastructure & 20 & 53 \\
TOTAL TRANSPORTATION & $10,041-10,467 /$ & $25,801-26,865 /$ \\
Fishing vessels & $9847 ; 9945 ; 12,041$ & 25,$318 ; 25,562 ; 30,798$ \\
\hline
\end{tabular}

* For a fleet with $100 \%$ of the projected aircraft demand. If the fleet size were $50 \%$ of that size, the corresponding figures would have to be multiplied, respectively, by this factor. ${ }^{* *}$ The three values correspond to the electrification of motorways, national roads and all roads, respectively. ${ }^{\dagger}$ If the whole inland transport of passengers and freight were provided by electrified railways, the results would be 13,909 billion USD and 34,744 PJ.

\section{Discussion and Conclusions}

In this work we analysed the energy costs required to transform the fossil-fuel-based EU transportation system to a new one based on renewable energy sources. The baseline scenario considers the substitution of the current road, railway, air and ship fleets. Together with the fleet substitution, we consider the cost of the basic infrastructures needed to keep the system operative. In the baseline scenario with recharging posts, the (primary) embodied energy required for the new transport system is $25,907 \mathrm{PJ}$ in the best case, $84 \%$ for vehicles, $7.7 \%$ for airplanes, $3.5 \%$ for ships, $2.6 \%$ for electrification of railways, $2.2 \%$ for recharging posts, and $0.2 \%$ for gas storage. This primary energy is approximately $50 \%$ of the final energy consumed in 2016 by all sectors [33] and 164\% of the final energy used by the transport sector in 2016. If the transition took place in 30 years, the annual energy that should be invested would be around $1.7 \%$ of the annual final energy (5.6\% the annual energy required by the transport sector). In the baseline scenario with TEV system for all EU roads, these figures would be $61 \%$ of the final energy of 2016 and an investment of $2 \%$ of final energy of 2016 per year.

Table 1 shows that the energy demanded for road, rail and fuel transport are lower in the renewable economy, but increases more than two times for shipping and air transport. The energy cost of the whole transportation system depends strongly on the fuel used for aircraft, revealing the importance of the strategy taken for the air transport sector as a way to achieve sustainability. The figures in Table 1 show how the energy consumed for all transport modes (except air and ship transport) would save energy after conversion to electricity that can be used to supply the costs for infrastructure changes.

As Table 1 shows, a 100\% renewable transport system providing the same service as EU transport in 2016 would consume around 16\% less energy. This saving is achieved by the transformation of road transport $(70 \%)$, due to the higher efficiency of battery motors in relation to combustion engines, and to a scant number of fuel cell vehicles (assumed to be only 10\% of commercial vehicles). The total consumption of land transport would be 3951.4 PJ. However, if train transport and twoand three-wheelers were encouraged to supply the entire land transportation demand, this figure would be 2808.6 PJ (12.6 PJ of these being consumed by electric two- and three-wheelers). This would supply the same service with $71 \%$ of the energy consumption and with no need to maintain a massive traffic system. 
Taking as a reference the EU-28 GDP of 14,800 billion USD (USD of 2016) in 2016 [55], in the baseline scenario with charging posts (Table 2), the required new infrastructure would cost $68-71 \%$ of the GDP of the EU-28 in 2016. Over a period of 30 years, the rate of investment should be $2.3-2.4 \%$ of the GDP per year if the infrastructure replacement were homogeneous. In reality, the replacement would not be uniform over time, but would increase in the moments when important fractions of the current infrastructure ended their useful life. The total annual investment would be 333 billion USD in the scenario with charging posts, and 400 billion USD per year in the scenario with electrification of all roads. This range is similar to the one estimated by Ram et al. [10] for their scenario of transport transition in Europe: 300-350 billion EUR (342-399 billion USD) per year during the transition. These costs might not all be government investments. Private and corporate spending might be part of this investment effort within a shared transition plan.

Regarding land transport, if a TEV system were implemented for all the national roads in the EU-28, the investment would be 132 billion USD, which is $57 \%$ of the charging station systems' minimum cost. However, if all the roads in the EU-28 had to be electrified, its capital investment would be 2228 billion USD, which is 3-10 times the cost of charging stations. In this case, the total investment for the transport system would be 12,071 billion USD and the investment rate would amount to $2.7 \%$ of the GDP per year. Taking into account the fact that EU capital formation was $19.7 \%$ of GDP in 2016 [56], such an investment seems achievable, although it needs to be linked to a similar investment in renewable production infrastructure.

In 2016, the EU and five cooperating countries (33 countries) invested 116 billion USD in transport infrastructure [57]. Compared to this figure, the investment in gas infrastructure plus charging posts would amount to $7-19 \%$, and the investment in gas infrastructure plus a TEV system for all EU-28 roads would cost $65 \%$ of that figure. Electrification of the whole road network seems to be a feasible option and would avoid the issue of a possible increase in scarce minerals used in batteries (which may be a bottleneck for the option of battery vehicles plus charging posts). A combination of charging posts and a TEV system for selected roads only is also possible. These two options can be combined with car sharing, which has the potential to reduce the fleet size to $7 \%$ of the present one [58] and would avoid problems for the middle class in buying electric vehicles, which are relatively expensive.

If we consider the all-rail scenario (substituting road transport with electrified trains) a complete substitution of the non-electrified land passenger and freight transport in the EU-28 would cost 13,909 billion USD (with an energy investment of 34,744 PJ). Thus, this transport fully based on trains would cost (both in monetary units and energy units) 1.5-1.6 times the cost of a future fleet of road vehicles of the same size as the present one, in addition to its electric recharging system (1.3 times the cost of that fleet with a TEV system for all of the EU-28 roads). To implement it, the rate of investment should be $3.4 \%$ of the GDP of the EU- 28 for 30 years. The required investment in railways, in USD per year, would be four times the investment in transport infrastructure of 2016, for 30 years. Although it would require economic effort, the scenario seems feasible with the present (moderate) percentage of high-speed lines, and then the re-structuring of land transport would reduce accidents, pollution, congestion in cities and the poor quality of life that the current traffic system generates.

It should be noted that a global fleet of vehicles as large as the present one would require a system of charging posts in towns which would not eliminate car congestion in our cities; moreover, that large fleet would cause a high price increase in nickel and lithium minerals, as $33 \%$ and $48 \%$ of the present reserves of $\mathrm{Li}$ and $\mathrm{Ni}$, respectively, would be used in the vehicles' batteries [21]. A great saving in scarce materials would be achieved if future EU roads had a ground-level (or overhead) line for power supply in both directions. A major substitution of long-distance truck commercial transport with railway transport would also solve the aforementioned problems, albeit at a higher investment cost.

Consistent with our analysis, a type of energy-efficient and quality land transport should ideally be based on electric trains for freight and passenger transport between cities, fleets of two- and three-wheeled electric vehicles as a minor complement to public transportation in municipalities, and electric vehicles for short-distance transport between cities and villages without trains. In this 
ideal scenario, traffic would greatly reduce and a modest infrastructure of charging posts would be sufficient. To implement it, the investment in transport infrastructure should be increased by a factor of 4 compared to the value of 2016, for a period of 30 years.

In the baseline scenario, the shipping and air sectors would greatly increase their energy demand: by $162 \%$ and $149 \%$, respectively (Table 1 ). This is because of the need to produce liquid natural gas to power the engines of planes and vessels. In a $100 \%$ RES, this would be made from electrolytic hydrogen (and $\mathrm{CO}_{2}$ ) or from urban and crop waste biodigestion.

These results, as well as other estimates [12], suggest large price increases and, in consequence, a decrease in maritime and air transport, which may lead to the relocation of some economic activities.

Energy cost is about $12 \%$ of the production cost of air transportation $[59,60]$. The ratio $\beta$ between future and present cost can be estimated from the corresponding ratio between the last two columns of Table 1 , and then a ratio between future and present final price can be obtained (Appendix A). If LNG were the fuel used, $\beta=2.49$ and $P^{\prime} / P$ would be 1.18 . If jet biofuel were the fuel used, $\beta=4.17$ and $P^{\prime} / P$ would be 1.38 .

If we assume that the elasticity of demand for leisure flights is similar in EU-28 than in the US, about -1.6 [61], we can expect a drop in demand by $29 \%$ (LNG) to $61 \%$ (jet biofuel) owing to purely economic reasons only.

To obtain an upper bound estimate of the embodied energy in a world transport transition, we repeated the calculations made in García-Olivares et al. [21] but with the embodied energy per USD used in this study. The results are displayed in Table A1 of Appendix B.

The embodied energy of a substitution of the whole world transport would amount to 149-158 EJ for the scenario with charging points, and 257 EJ for the scenario with a TEV system on all roads in the world. Even with our pessimistic hypothesis, a 30-year transition for the world baseline scenario would require only $4.8 \%$ of the energy demanded per year for the transport sector [32], which seems to be an achievable goal.

The assumptions made in this analysis do not consider major changes in the markets for raw materials on the demand side, which would also (likely) exceed current production capacity by a considerable margin and result in price increases. However, it may lead to a lowering of prices as production capacity has been ramped up and made more efficient, and cheaper alternatives to costly raw materials have been developed. This will affect the capital and energy required for the transition. It should also be mentioned that such changes in price will strongly depend on the policies applied by governments, which will allow them to regulate the pace of the transition, as well as the consumption rate of raw materials in the EU and also in the world as a whole. Detailed analysis of such factors and their implications is out of the scope of our study, and it would require the use of modelling tools to account, for instance, for the non-linear links between market fluctuation, raw material production and the pace of the transition.

This study could be expanded to analyse the costs that would be required for the renewable conversion of the vehicles, ships and aircrafts of the EU army. This transition would be very different for different geopolitical scenarios that we can imagine for a future renewable European economy integrated into the global economy. Thus, we prefer to leave that analysis for a future article.

One last conclusion of this study is that (both for the EU and the world) the substitution of land transport would save a greater amount of fossil energy (and therefore, $\mathrm{CO}_{2}$ ) per unit of investment and should be addressed initially, while air and ship transport system substitution could be the last steps of the transition.

Author Contributions: Conceptualization, A.G.-O. and J.S.; methodology, A.G.-O. and J.S.; software, A.G.-O., R.S. and J.B.-P.; validation, A.G.-O. and J.S.; formal analysis, A.G.-O. and R.S.; investigation, A.G.-O., J.S. and R.S.; resources, A.G.-O., J.S. and R.S.; data curation, A.G.-O. and J.B.-P.; writing-original draft preparation, A.G.-O. and J.S.; writing-review and editing, J.B.-P. and R.S.; visualization, J.S. and J.B.-P.; supervision, R.S.; project administration, J.S.; funding acquisition, J.S. All authors have read and agreed to the published version of the manuscript. 
Funding: This study was founded by the European Union, MEDEAS project ("Modeling the Renewable Energy Transition in Europe", European Union's Horizon 2020 research and innovation program, grant agreement No 691287 of the Framework Program for Research and Innovation actions, H2020 LCE-21-2015).

Acknowledgments: The authors thank the two anonymous reviewers for their comments and suggestions for improving the manuscript.

Conflicts of Interest: The authors declare no conflict of interest. The funders had no role in the design of the study; in the collection, analyses, or interpretation of data; in the writing of the manuscript, or in the decision to publish the results.

\section{Appendix A.}

If the present fuel cost for flight operation $(C)$ is a fraction $\alpha$ of the total production $\operatorname{cost} P, C=\alpha P$. If the future cost for flight operation $\left(C^{\prime}\right)$ is $\beta$ times the present cost, $C^{\prime}=\beta C$.

The future production cost $\left(P^{\prime}\right)$ of air transport would be given by the following expression:

$P^{\prime}=C^{\prime}+(1-\alpha) P=\beta C+(1-\alpha) P=\alpha \beta P+(1-\alpha) P=[\alpha \beta+(1-\alpha)] P$

Therefore, the ratio between $P^{\prime}$ and $P$ would be:

$P^{\prime} / P=[\alpha \beta+(1-\alpha)]$

We assume that the ratio between the future and present price will be equal to the ratio between future and present production cost. $\beta$ can be estimated from the corresponding ratio between the last two columns of Table 1, since operation fuels accounts for most of the energy used in the sector. If liquified natural gas were the fuel used, $\beta=2.49$ and $P^{\prime} / P$ would be 1.18 . If jet biofuel were the fuel used, $\beta=4.17$ and $P^{\prime} / P$ would be 1.38 .

\section{Appendix B. Capital Cost and Embodied Energy of the Decarbonized World Transport}

Table A1. Capital cost of the decarbonized world transport (column 2), and its embodied energy with the hypotheses of García-Olivares et al. [21] (column 3), and with the energy intensity used in the present study (column 4).

\begin{tabular}{|c|c|c|c|}
\hline Sector & $\begin{array}{l}\text { Capital Cost } \\
\text { (Billion USD) }\end{array}$ & $\begin{array}{c}\text { Embodied Energy (PJ) } \\
\text { (Lower Bound) }\end{array}$ & $\begin{array}{c}\text { Embodied Energy (PJ) } \\
\text { (Upper Bound) }\end{array}$ \\
\hline Light-duty vehicles & 22,854 & 9642 & 86,398 \\
\hline Medium- and high-duty trucks & 9315 & 3930 & 35,215 \\
\hline Two- and three-wheelers & 3422 & 1444 & 12,937 \\
\hline TOTAL VEHICLES & 35,591 & 15,016 & 134,549 \\
\hline Railways ${ }^{+}$ & 201 & 85 & 835 \\
\hline Locomotives $^{\text {t+ }}$ & 1205 & 497 & 5645 \\
\hline TOTAL RAILWAYS & 1406 & $579^{+}$ & 6480 \\
\hline Bulk carrier ships & 511 & 220 & 1835 \\
\hline General cargo ships & 107 & 46 & 384 \\
\hline Container ships & 275 & 119 & 989 \\
\hline Chemical tankers & 94 & 40 & 337 \\
\hline Passenger ships & 154 & 66 & 553 \\
\hline TOTAL SHIPPING & 1107 & 477 & 4099 \\
\hline Aircraft * & 1613 & 397 & 3844 \\
\hline Recharging stations $\ddagger /$ & 1184/ & $488 /$ & $4438 /$ \\
\hline TEV system & 52,881 & 21,796 & 112,328 \\
\hline Biomethane infrastructure & 79 & 290 & $290^{*}$ \\
\hline TOTAL & $40,979 /$ & $17,248 /$ & $153,700 /$ \\
\hline TRANSPORTATION & 92,675 & 38,555 & 261,590 \\
\hline Fishing vessels & 1790 & 772 & 6308 \\
\hline
\end{tabular}

${ }^{+}$Calculation updated with the length of world tracks $\left(1.75 \times 10^{6} \mathrm{~km}\right)$, high-speed lines $(29,000 \mathrm{~km})$ and electrified fraction (32.5\%) taken from [62], the length of railway lines $\left(1.15 \times 10^{6} \mathrm{~km}\right)$ taken from [63], and assuming that all single-track lines are not electrified. ${ }^{+\dagger}$ Calculation updated with a locomotive mean price of 4 million USD and assuming $67 \%$ of non-electric locomotives. $\ddagger$ Calculations updated to correct an inconsistency found in García-Olivares et al. [21] * For a 50\% reduction in the aircraft fleet. For a scenario with electrification of all of the world's roads. * No range is provided since the embodied energy was estimated directly, and not by an energy intensity analysis. 


\section{References}

1. ECMT, European Comision Mobility and Transport. Statistical Pocketbook 2018; EU Transport in Figures; Publications Office of the European Union: Luxembourg, 2018; Available online: https://ec.europa.eu/ transport/facts-fundings/statistics/pocketbook-2018_en (accessed on 19 June 2020).

2. EC Logistics. Transport Sector Economic Analysis. EU Science Hub, The European Commission's Science and Knowledge Service. 2018. Available online: https://ec.europa.eu/jrc/en/research-topic/transport-sectoreconomic-analysis (accessed on 19 June 2020).

3. EEA. Greenhouse Gas Emissions from Transport in Europe. European Environment Agency. 2019. Available online: https:/www.eea.europa.eu/data-and-maps/indicators/transport-emissions-of-greenhouse-gases/ transport-emissions-of-greenhouse-gases-12 (accessed on 19 June 2020).

4. EC. A European Strategy for Low-Emission Mobility. Communication From The Commission To The European Parliament, The Council, The European Economic and Social Committee and The Committee of The Regions. Commission Staff Working Document Accompanying the document. Brussels. 20 July 2016. Available online: https:/ec.europa.eu/transport/sites/transport/files/themes/strategies/news/doc/2016-07-20decarbonisation/swd\%282016\%29244.pdf (accessed on 19 June 2020).

5. Eurostat Freight Split. Freight Transport Statistics-Modal Split. 2016. Available online: https://ec.europa.eu/ eurostat/statistics-explained/index.php?title=Freight_transport_statistics (accessed on 19 June 2020).

6. Statista Mileage. Passenger Mileage in the EU-28 in 2016, by Mode (in Billion Passenger Kilometers). 2016. Available online: https://www.statista.com/statistics/280519/passenger-mileage-in-eu-27-by-mode/ (accessed on 19 June 2020).

7. EC White Paper, Roadmap to a Single European Transport Area-Towards a Competitive and Resource Efficient Transport System. White Paper. Brussels. 283 2011. Available online: https://eur-lex.europa.eu/ legal-content/EN/TXT/PDF/?uri=CELEX:52011DC0144\&from=EN (accessed on 19 June 2020).

8. Jacobson, M.Z.; A Delucchi, M. Providing all global energy with wind, water, and solar power, Part I: Technologies, energy resources, quantities and areas of infrastructure, and materials. Energy Policy 2011, 39, 1154-1169. [CrossRef]

9. García-Olivares, A.; Poy, J.B.; García-Ladona, E.; Turiel, A.; García-Ladona, E. A global renewable mix with proven technologies and common materials. Energy Policy 2012, 41, 561-574. [CrossRef]

10. Ram, M.; Bogdanov, D.; Aghahosseini, A.; Gulagi, A.; Oyewo, A.S.; Child, M.; Caldera, U.; Sadovskaia, K.; Farfan, J.; Barbosa, L.S.N.S.; et al. Global Energy System based on 100\% Renewable Energy-Energy Transition in Europe Across Power, Heat, Transport and Desalination Sectors. Available online: https://www.evelinelemke.de/wp-content/uploads/2019/01/EWG-LUT_Full-Study_Energy-Transition-Europe.pdf (accessed on 19 June 2020).

11. García-Olivares, A. Substitutability of Electricity and Renewable Materials for Fossil Fuels in a Post-Carbon Economy. Energies 2015, 8, 13308-13343. [CrossRef]

12. Gilbert, R.; Perl, A. Transport Revolutions: Moving People and Freight without Oil; New Society Publishers: Vancouver, BC, Canada, 2008.

13. Sims, R.R.; Schaeffer, F.; Creutzig, X.; Cruz-Núñez, M.; D’Agosto, D.; Dimitriu, M.J.; Figueroa Meza, L.; Fulton, S.; Kobayashi, O.; Lah, A.; et al. Transport. In Climate Change 2014: Mitigation of Climate Change; Edenhofer, O., Pichs-Madruga, R., Sokona, Y., Farahani, E., Kadner, S., Seyboth, K., Adler, A., Baum, I., Brunner, S., Eickemeier, P., et al., Eds.; Contribution of Working Group III to the Fifth Assessment Report of the ntergovernmental Panel on Climate Change; Cambridge University Press: Cambridge, UK; New York, NY, USA, 2014.

14. Teske, S.; Sawyer, S.; Schäfer, O.; Pregger, T.; Simon, S.; Naegler, T. Energy [R] evolution-A Sustainable World Energy Outlook. 2015. Available online: https://elib.dlr.de/98314/ (accessed on 19 June 2020).

15. King, C.; Vecia, G.; Thompson, I. Innovative Technologies for Light Rail and Tram: A European Reference Resource. Briefing Paper 2, Ground-Level Power Supply. Sintropher Cooperation Project, Interreg IVB North West Europe. European Commission. 2015. Available online: https:/www.polisnetwork.eu/wp-content/ uploads/2019/06/alimentation-pas-le-sol-2-finalpolis.pdf (accessed on 19 June 2020).

16. IRENA. The Renewable Route to Sustainable Transport: A Working Paper Based on REmap; International Renewable Energy Agency: Abu Dhabi, UAE, 2016. Available online: https://www.irena.org/publications/2016/Aug/TheRenewable-Route-to-Sustainable-Transport-A-working-paper-based-on-REmap (accessed on 19 June 2020). 
17. Edelstein, S. Road for Electric Trucks with Trolley-Like Catenary Opens in Sweden. Green Car Reports. 10 July 2016. Available online: http://www.greencarreports.com/news/1104908_road-for-electric-truckswith-trolley-like-catenary-opens-in-sweden (accessed on 19 June 2020).

18. Swenson, R. The Solarevolution: Much More with Way Less, Right Now-The Disruptive Shift to Renewables. Energies 2016, 9, 676. [CrossRef]

19. Thomas, S. Sustainable Transportation Options for the 21st Century and Beyond: A Comprehensive Comparison of Alternatives to the Internal Combustion Engine; Springer: Berlin, Germany.

20. Arbib, J.; Seba, T. Rethinking Transportation 2020-2030. A RethinkX Sector Disruption Report. 2017. Available online: www.rethinkx.com. (accessed on 19 June 2020).

21. García-Olivares, A.; Solé, J.; Osychenko, O. Transportation in a $100 \%$ renewable energy system. Energy Convers. Manag. 2018, 158, 266-285. [CrossRef]

22. Matthews, H.S.; Hendrickson, C.T.; Matthews, D.H. Life Cycle Assessment: Quantitative Approaches for Decisions That Matter. Available online: www.lcatextbook.com (accessed on 19 June 2020).

23. Miketa, A. Analysis of energy intensity developments in manufacturing sectors in industrialized and developing countries. Energy Policy 2001, 29, 769-775. [CrossRef]

24. Volkswagen. The Golf Environmental Commendation Background Report; Volkswagen AG Group Research: Wolfsburg, Germany, 2010.

25. Lewis, T. A Life Cycle Assessment of the Passenger Air Transport System Using Three Flight Scenarios. Master's Thesis, Norwegian University of Science and Technology, Trondheim, Norway, 2013.

26. Jet News. Boeing, Airbus y Bombardier: El Costo de los Tres Gigantes. Jet News, In Spanish. 13 September 2017. Available online: http://jetnews.com.mx/boeing-airbus-y-bombardier-el-costo-de-lostres-gigantes/ (accessed on 19 June 2020).

27. World Energy Council. Energy Efficiency Indicators. 2016. Available online: https://wec-indicators.enerdata. net/secteur.php\#/industry-energy-intensity-world-level-trends.html (accessed on 19 June 2020).

28. ACEA. ACEA Report Vehicles in Use Europe 2018. European Automobile Manufacturers Association. Brussels. 2018. Available online: https://www.acea.be/statistics/article/report-vehicles-in-use-europe-2018 (accessed on 19 June 2020).

29. ICCT. European Vehicle Market Statistics, Pocketbook 2018/19. ICCT, the International Council on Clean Transportation. 2018. Available online: http://eupocketbook.theicct.org (accessed on 19 June 2020).

30. Serrano, J. Ránking: Los 25 Coches y SUV más vendidos en Europa en lo que va de año. Available online: https://www.autopista.es/noticias-motor/articulo/ranking-los-25-coches-y-suv-mas-vendidos-eneuropa-en-lo-que-va-de-ano (accessed on 19 June 2020). (In Spanish).

31. Whitbread, C. EU Heavy Truck Market Sees 19.4\% Gain in 2015; Positive Expectations for 2016. Just Auto. 9 February 2016. Available online: https://www.just-auto.com/analysis/eu-heavy-truck-market-sees-194gain-in-2015-positive-expectations-for-2016_id167007.aspx (accessed on 19 June 2020).

32. IEA Sankey. World Final Consumption. Sankey Diagram. 2016. Available online: https://www.iea.org/ Sankey/\#?c=World\&s=Final\%20consumption (accessed on 19 June 2020).

33. Eurostat. Energy Balance Flow for EU28 2016. Sankey Diagram. 2016. Available online: https://ec.europa.eu/ eurostat/web/energy/energy-flow-diagrams (accessed on 19 June 2020).

34. Thien, L.D. Forecasting the Dry Bulk Freight Market; World Maritime University: Malmö, Sweden, 2005; Available online: http://commons.wmu.se/all_dissertations/242 (accessed on 19 June 2020).

35. EUAR. Report on Railway Safety and Interoperability in the EU 2018; European Union Agency for Railways: Valenciennes, France, 2018; Available online: https://www.era.europa.eu/sites/default/files/library/docs/ safety_interoperability_progress_reports/railway_safety_and_interoperability_in_eu_2018_en.pdf (accessed on 19 June 2020).

36. Ferropedia. Costos de Construcción de Infraestructura (in Spanish). 2017. Available online: http: //www.ferropedia.es/mediawiki/index.php/Costos_de_construcci\%C3\%B3n_de_infraestructura (accessed on 19 June 2020).

37. Gattuso, D.; Restuccia, A. A Tool for Railway Transport Cost Evaluation. Procedia Soc. Behav. Sci. 2014, 111, 549-558. [CrossRef]

38. Eurostat Freight. Inland Freight Transport, 2016.png. 2016. Available online: https://ec.europa.eu/eurostat/ statistics-explained/index.php?title=File:Inland_freight_transport,_2016.png\&oldid=386908 (accessed on 19 June 2020). 
39. Eurostat Locomotives. Number of locomotives and railcars in Europe in 2016, by Country. European Comission. EU Transport in Figures: Statistical Pocketbook, table 2.6.15, page 101. 2018.

40. Baumgartner, J.P. Prices and Costs of the Railway Sector; École Politechnique Fédérale de Laussanne: Laussanne, Switzerland, 2001.

41. TEV. The TEV Project. Tracked Electric Vehicle System. 2017. Available online: http://tevproject.com/ (accessed on 19 June 2020).

42. Odysee Mure. Change in Distance Travelled by Car. 2019. Available online: http://www.odyssee-mure.eu/ publications/efficiency-by-sector/transport/distance-travelled-by-car.html (accessed on 19 June 2020).

43. Bureau of Transportation. Transportation Statistics Annual Report 2012; Bureau of Transportation Statistics; US Department of Transportation: Washington, DC, USA, 2012; Chapter 2. Available online: https://www.bts. gov/archive/publications/transportation_statistics_annual_report/2012/chapter2 (accessed on 19 June 2020).

44. UITP. Mobility in Cities Database-Synthesis Report; UITP Advancing Public Transport: Brussels, Belgium, 2015.

45. López-Lambas, M.E.; Monzón, A.; Pieren, G. Analysis of using electric car for urban mobility, perceived satisfaction among university users. Transp. Res. Procedia 2017, 27, 524-530. [CrossRef]

46. Bösch, P.; Becker, F.; Becker, H.; Axhausen, K.W. Cost-based analysis of autonomous mobility services. Transp. Policy 2018, 64, 76-91. [CrossRef]

47. Engel, H.; Hensley, R.; Knupfer, S.; Sahdev, S. Charging Ahead: Electric Vehicle Infrastructure Demand. McKinsey Center for Future Mobility. Report of October. 2018. Available online: https://www.mckinsey.com/ \{\}/media/McKinsey/Industries/Automotive\%20and\%20Assembly/Our\%

20Insights/Charging\%20ahead\%20Electric-vehicle\%20infrastructure\%20demand/Charging-ahead-electricvehicle-infrastructure-demand-final.ashx (accessed on 19 June 2020).

48. Wallbox. Postes de Recarga. The Wallbox Sotre. 2017. Available online: http://wallbox.eu/es/wallbox/postesde-recarga/ (accessed on 19 June 2020).

49. IEA. Energy Technology Perspectives 2016; International Energy Agency, OECD/IEA: Paris, France, 2016. Available online: https://www.iea.org/reports/energy-technology-perspectives-2016 (accessed on 19 June 2020).

50. IEA. The Future of Trucks-Implications for Energy and the Environment; International Energy Agency, OECD/IEA: Paris, France, 2017; Available online: https:/www.lowcvp.org.uk/assets/reports/ TheFutureofTrucksImplicationsforEnergyandtheEnvironment.pdf (accessed on 19 June 2020).

51. EU Road Federation. Road Network 2017. Length of Total Road Network by Category by Country, End of 2013 (km). 2017. Available online: https://erf.be/wp-content/uploads/2018/01/Road_statistics_2017.pdf (accessed on 19 June 2020).

52. Rotoli, F.; Malavasi, G.; Ricci, S. Complex railway systems: Capacity and utilisation of interconnected networks. Eur. Transp. Res. Rev. 2016, 8, 29. [CrossRef]

53. ASTM International. ASTM Standard Practice for Qualification and Approval of New Aviation Turbine fFuels and Fuel Additives. ASTM D4054-17. 2014. Available online: http://www.astm.org/cgi-bin/resolver. cgi?D4054-17 (accessed on 19 June 2020).

54. EAER. European Aviation Environmental Report 2016. European Environment Agency, European Aviation Safety Agency, and Eurocontrol. 2016. Available online: https:/ec.europa.eu/transport/sites/transport/files/ european-aviation-environmental-report-2016-72dpi.pdf (accessed on 19 June 2020).

55. Eurostat GDP. 2019. Available online: https://ec.europa.eu/eurostat/statistics-explained/index.php?title=File: GDP_at_current_market_prices,_2006_and_2014-2016_YB17.png (accessed on 19 June 2020).

56. World Bank. Gross Fixed Capital Formation (\% of GDP). 2019. Available online: https://data.worldbank.org/ indicator/NE.GDI.FTOT.ZS?end=2017\&locations=EU-AT-PL-\&start=1970 (accessed on 19 June 2020).

57. European Environment Agency. 2019. Available online: https://www.eea.europa.eu/data-and-maps/ indicators/infrastructure-investments/assessment-3 (accessed on 19 June 2020).

58. Mounce, R.; Nelson, J.D. On the potential for one-way electric vehicle car-sharing in future mobility systems. Transp. Res. Part A Policy Pr. 2019, 120, 17-30. [CrossRef]

59. ICAO. Airline Operating Costs and Productivity; The International Civil Aviation Organization: Tehran, Iran, 20-23 February 2017; Available online: https://www.icao.int/MID/Documents/2017/Aviation\%20Data\% 20and\%20Analysis \%20Seminar/PPT3\%20-\%20Airlines \%20Operating\%20costs $\% 20$ and \%20productivity. pdf (accessed on 19 June 2020). 
60. Beers, B. Which Major Expenses Affect Airline Companies? Investopedia. Available online: https://www. investopedia.com/ask/answers/040715/what-are-major-expenses-affect-companies-airline-industry.asp (accessed on 19 June 2020).

61. Belobaba, P.; Odoni, A.R.; Barnhart, C. The Global Airline Industry. John Wiley \& Sons: West Suxxex, UK, 2009.

62. IEA-UIC. Railway Handbook 2015. Energy Consumption and $\mathrm{CO}_{2}$ Emissions. International Energy Agency and International Union of Railways; International Energy Agency: Paris, France, 2015; Available online: https://uic.org/sustainable-development/energy-and-co2-emissions/uic-iea-railway-handbook (accessed on 19 June 2020).

63. CIA World Factbook, Railways, Country Comparison. The World Factbook. Library of the Central Intelligence Agency. USA Government. 2017. Available online: https://www.cia.gov/library/publications/the-worldfactbook/rankorder/2121rank.html (accessed on 21 June 2020).

(C) 2020 by the authors. Licensee MDPI, Basel, Switzerland. This article is an open access article distributed under the terms and conditions of the Creative Commons Attribution (CC BY) license (http://creativecommons.org/licenses/by/4.0/). 